\title{
Fragment-based drug discovery of carbonic anhydrase II inhibitors by dynamic combinatorial chemistry utilizing alkene cross metathesis
}

\author{
Sally-Ann Poulsen* and Laurent F. Bornaghi
}

Chemical Biology Group, Eskitis Institute for Cell and Molecular Therapies, Griffith University, Nathan campus, Brisbane 4111, Australia

*Author to whom correspondence should be addressed (fax +61 73735 7656, tel. +61 73735 7825,emails.poulsen@griffith.edu.au)

\begin{abstract}
-
A fragment-based drug discovery approach to the synthesis and identification of small molecule inhibitors of bovine carbonic anhydrase II (bCA II) is described. The classical bCA II recognition fragment is an aromatic sulfonamide $\left(\mathrm{ArSO}_{2} \mathrm{NH}_{2}\right)$ moiety. This fragment was incorporated into a scaffold building block, which was subsequently derivatized by dynamic combinatorial chemistry utilizing alkene cross metathesis as the reversible reaction. Screening against bCA II was then carried out and the results allowed determination of the relative bCA II binding affinities of the cross metathesis products that contained the $\mathrm{ArSO}_{2} \mathrm{NH}_{2}$ fragment. A bCA II competitive binding assay validated these results with a representative number of pure compounds. The results for screening, without prior isolation of the active constituent, were in full agreement with those obtained for equilibrium dissociation constants (Ki's) of pure compounds. Some of these compounds exhibited Ki's in the low nanomolar range. Heterogeneous catalysis was shown to be very effective in this drug discovery application of dynamic combinatorial chemistry.
\end{abstract}

\section{Keywords -}

cross metathesis; dynamic combinatorial chemistry; carbonic anhydrase; sulphonamide; fragment-based drug discovery 


\section{Introduction}

Dynamic combinatorial chemistry (DCC) exploits reversible covalent reactions to synthesize libraries of molecules. Unlike conventional synthesis, DCC proceeds not to generate high yielding pure compounds, but rather to access diversity and enable amplification of the 'best binder' by interaction of dynamic combinatorial library (DCL) constituents with a target in a self-screening protocol. ${ }^{1,2}$ Drug discovery applications of DCC require reaction conditions that do not disrupt the target's function or structure. Specifically, this means that (i) reaction at a biologically relevant temperature (ii) compatibility with aqueous media (iii) reaction at (close to) physiological $\mathrm{pH}$, and (iv) compatibility with the target functional groups, are each necessary to enable ligand amplification from DCLs when generated in the presence of a protein target. ${ }^{1,2}$ The concept of a pre-equilibrated DCL (pDCL) has also been described wherein the DCL is prepared in the absence of the protein target, and the library screened post-synthesis for identification of components with affinity for the protein target. ${ }^{3,4}$ This approach may be applied when the stringent criteria just described cannot be met. While the pDCL approach does not permit the amplification of the best binder(s) it does still benefit from the ease and potentially greater diversity generated in DCC synthesis owing to reversible covalent reactions. There are now multiple examples of drug discovery from both DCLs generated in the presence of a protein target (through ligand amplification) and pDCLs generated prior to screening against the protein target. ${ }^{3-14}$ Each of these reported examples has drawn upon a pre-existing knowledge of the protein-small molecule system and collectively they represent a special application of fragment-based drug discovery optimisation methodology. ${ }^{15}$ This manuscript describes our efforts towards fragment-based drug discovery of carbonic anhydrase II (CA II) inhibitors utilizing DCC with alkene cross metathesis (CM) as the reversible reaction. CM has often been cited alongside transimination (of imines, oximes and hydrazones) and disulfide exchange as a promising reversible reaction for drug discovery applications of DCC. While examples of imine exchange, and to a lesser extent disulfide exchange, now abound this is not so for $\mathrm{CM}^{2-14}$ There is only one reported example of CM operating close to the stringent criteria described above wherein Nicolaou and coworkers employed a biphasic reaction medium to link vancomycin monomers by CM in the presence of D-Ala-D-Ala type targets. ${ }^{16}$ The biphasic system was necessary as commercially available CM catalysts are not sufficiently water soluble to operate in a completely aqueous reaction medium. There are no reported DCC drug discovery applications of CM where the target is a protein. 
The carbonic anhydrase (CA) family of Zn(II) metalloenzymes (EC 4.2.1.1) catalyses the interconversion of $\mathrm{CO}_{2}$ and $\mathrm{HCO}_{3}^{-}$, a reaction that underpins many physiological processes associated with $\mathrm{pH}$ control, ion transport and fluid secretion. ${ }^{17,18}$ As a target for drug intervention, inhibitors of CA have been used clinically for the treatment of glaucoma, epilepsy and gastric ulcers. ${ }^{17,18}$ More recently CA inhibition has been implicated as playing an important role in cancer tumor progression. ${ }^{19-21}$ Successful development of small molecule inhibitors of CA has been accomplished using a fragment-based drug discovery methodology wherein various aromatic or heteroaromatic sulfonamides $\left(\mathrm{ArSO}_{2} \mathrm{NH}_{2}\right)$ - the classical bCA II recognition motif - are derivatized to optimise for CA affinity, CA isozyme selectivity (there are 16 human CA isozymes known) and desirable pharmaceutical properties. ${ }^{17,18}$ Clinically used CA inhibitors include acetazolamide, methazolamide, ethoxazolamide, dichlorophenamide, brinzolamide and dorzolamide (Fig. 1). Indisulam is in Phase II clinical trials as an anticancer agent to treat solid tumors (Fig. 1). ${ }^{21}$

\section{Insert Figure 1}

The alkene metathesis reaction, using the carbene ruthenium catalysts developed by Grubbs, is well studied for conventional organic chemistry applications. ${ }^{22,23}$ The CM variant of this reaction generates alkenes that are either homodimers (from self-CM) or heterodimers. As well both trans or cis geometry about the newly formed alkene bonds is possible (Fig. 2). Despite the variable product distributions possible from CM the general utility of this reaction has recently been extended by the development of a model that classifies alkene reactivity towards $\mathrm{CM}^{24}$ Classifications range from Type I alkenes (those which undergo rapid self$\mathrm{CM}$ ) through to Type IV alkenes (those which are inert to CM). Based on this classification potentially large differences in the CM rate from structurally diverse alkene building blocks can be expected. This paper demonstrates that this need not translate into complications for DCC applications of CM that take advantage of the reversible nature of the reaction.

\section{Insert Figure 2}

\section{Results and Discussion}




\subsection{Design of building blocks}

Building block 1, an allyl ester benzene sulfonamide, was prepared specifically as a scaffold building block to facilitate this study (Fig. 3A). The dual functionality of 1, possessing an aromatic sulfonamide moiety and an allyl substituent, was designed to support both fragmentbased drug discovery (through provision of the bCA II recognition fragment for reliable bCA II affinity) and evaluation of CM chemistry for DCC (through provision of a terminal alkene functionality). Ten additional building blocks A-J (each containing a terminal alkene functionality and therefore able to undergo CM with 1) were also synthesized (Fig. 3B). Building blocks A-G were derived from amino acids and contained either a tertiary $\mathrm{N}$ allylamide moiety (A-C) or a vinyl benzene moiety (D-G). Building blocks I and $\mathbf{J}$ were aromatic allyl esters, while $\mathbf{H}$ was an aliphatic allyl ester. A-J were selected to introduce diversity onto the scaffold building block 1 and so enable exploration of potential secondary recognition interactions that may complement the well known bCA II interaction with an aromatic sulfonamide fragment.

\section{Insert Figure 3}

\subsection{Cross metathesis chemistry}

Initial experiments were designed to demonstrate both the reversibility of the CM reaction and its utility for DCC. Heterogeneous catalysis has not before been applied to DCC, but appears well suited to facilitate the reaction start-stop requirements of drug discovery applications: simple filtration to remove the catalyst (stop sequence), and addition/re-addition of catalyst (start sequence). In principle the start-stop sequence could be repeated many times without interfering with the overall DCL composition, unlike homogeneous catalysis that necessitates the 'permanent' addition of reagents to the DCL to achieve the same outcome. Grubbs first-generation catalyst was available commercially as an immobilized reagent and was employed in this study. CM of building blocks was performed by reaction with $20 \mathrm{~mol} \%$ catalyst in 1,2-dichloroethane (1,2-DCE) as solvent at $50{ }^{\circ} \mathrm{C}$ for $24 \mathrm{~h}$. Negative ion ESI MS analysis permitted detection of $\mathrm{CM}$ products of interest, that is those containing the sulfonamide moiety (detected as an $\mathrm{RSO}_{2} \mathrm{NH}^{-}$anion).

For this set of experiments 2a (the trans self-CM product of $\mathbf{1}$ ) was chosen as starting material so as to eliminate the competing self-CM reaction of $\mathbf{1}$. We have previously reported the (non- 
CM) synthesis of the trans and cis isomers of $\mathbf{2} \mathbf{a b}$, compounds $\mathbf{2 a}$ and $\mathbf{2} \mathbf{b}$, respectively (Fig. 3C). ${ }^{25}$ The characterization data for $2 \mathbf{a b}$ (prepared by CM) was consistent with that for the predominantly trans isomer 2a. CM of 2a (25 mM) with building block A (50 mM) resulted in formation of heterodimer $\mathbf{1 A}$, as evidenced in the mass spectrum (Fig. 4, entry A). The addition of $\mathbf{C}$ to the equilibrated $\mathrm{CM}$ reaction then led to incorporation of $\mathbf{C}$ with product $\mathbf{1 C}$, in addition to 2a and 1A, all visible in the negative ion mass spectrum (Fig. 4, entry B). When building block $\mathbf{C}$ was added after removal of the immobilized metathesis catalyst (by filtration) then no incorporation of $\mathbf{C}$ occurred, even after $72 \mathrm{~h}$ of reaction (mass spectrum identical to Fig. 4, entry A). Upon re-addition of fresh catalyst full incorporation of $\mathbf{C}$ was observed (mass spectrum identical to Fig. 4, entry B). An extended sequence of start-stop cycles was also possible (data not shown). Identical experiments were repeated with a range of building blocks and all results confirmed that the CM reaction was indeed operating reversibly and that the start-stop methodology for initiation, subsequent quenching, and reinitiation of the CM reaction was very effective.

\section{Insert Figure 4}

\subsection{Preparation and screening of pDCLs for bCA II affinity}

To confirm the premise that the aromatic sulfonamide moiety was indeed a prerequisite for bCA II recognition we first screened the simplest possible pDCLs generated by CM of our 11 building blocks. These reactions each contained one building block as starting material (1, A$\mathbf{J}$ ) and the only products were those from self-CM, being 2ab and AA-JJ (Fig. 5A). As these simple pDCLs were devoid of the heterodimer products $\mathbf{1 A - 1 J}$, they also served as convenient controls for background bCA II affinity in subsequent DCLs that contained the homodimers 2ab and AA-JJ, as well as heterodimers 1A-1J. The pDCL reactions were prepared similarly to that described above. The 12 pDCLs (11 from building blocks and one control containing only immobilized metathesis catalyst) were then assessed for bCA II enzyme binding by a fluorescence-based assay. This assay relies on the competition between the ligand 5(dimethylamino)-1-napthalenesulfonamide (DNSA) and the test compounds for the active site of bCA II. ${ }^{17,26,27}$ A complete description of the assay procedure has been described elsewhere. ${ }^{28}$ Screening of each pDCL at $1 \mu \mathrm{M}$ and $10 \mu \mathrm{M}$ (based on theoretical CM product concentration) was carried out. The results for the $10 \mu \mathrm{M}$ screen, expressed as percentage retention of the DNSA control binding, are presented in Figure 5B. With the exception of the pDCL from 1, which displaced 88\% of DNSA, none of the pDCLs (including the control) 
contained molecules that displaced DNSA from the binding site of bCA II (100\% DNSA retention). These results provided confirmation that the aromatic sulfonamide was a necessary fragment for bCA II recognition with only the self-CM product 2ab (a bis-sulfonamide), and not self-CM products AA through to $\mathbf{J J}$ (devoid of the bCA II recognition fragment), demonstrating affinity for bCA II. The remainder of this paper describes our DCC strategy for determining the relative bCA II affinities of the aromatic sulfonamide containing CM heterodimers $\mathbf{1 A - 1 J}$ in the presence of the common background of $\mathbf{2} \mathbf{a b}$ and the inactive homodimers AA-JJ.

\section{Insert Figure 5}

The previous section demonstrated that only the symmetrical bis-sulfonamide $\mathbf{2 a b}$ would be responsible for the background bCA II binding affinity response in pDCLs generated from CM of $\mathbf{1}$ with A-J. To minimize the background bCA II affinity of 2ab in DCLs we elected to use 10 equivalents of A-J as the CM partner of $\mathbf{1}$ (Fig. 6A). The effect of this biased stoichiometry was to increase the proportion of the heterodimer $C M$ products $\mathbf{1 A - 1 J}$ relative to the self-CM product 2ab compared for when equimolar amounts of $\mathbf{1}$ and A-J were reacted. ${ }^{24}$ The negative ion ESI MS analysis revealed that the CM of $\mathbf{1}$ with $\mathbf{A}$ produced the homodimer 2ab ( $<5 \%)$ but predominantly the hetereodimer 1A ( 90\%), similarly for CM of $\mathbf{1}$ with building blocks B-J. As 1A-1J each contained the aromatic sulfonamide fragment they were expected to exhibit some affinity for bCA II. The collective library was then screened at $1 \mu \mathrm{M}$ and $10 \mu \mathrm{M}$, the results for the $10 \mu \mathrm{M}$ screen, expressed as percentage retention of the DNSA from bCA II, are displayed in Figure 6B. The homodimerization self-CM reaction of 1 (to generate 2ab) is included in Figure 6B for comparison.

\section{Insert Figure 6}

The bCA II screening results presented in Figure 6B demonstrated that the CM products 1A$\mathbf{1 J}$ exhibited variable affinity for bCA II. These compounds each contained the core bCA II recognition fragment of $\mathbf{1}$, hence observed variations in affinity were likely to have arisen from secondary binding interactions introduced onto the aromatic sulfonamide fragment by the CM reaction. Analysis of the relative trends in affinity revealed that the most potent CM product was $\mathbf{1 H}$ with a terminal acetate group (77\% displacement of DNSA), more potent than the bulkier ester analogues, benzoate (1I) and p-phenyl benzoate (1J) with $45 \%$ and 37\% 
displacement of DNSA, respectively. Analogues 1A and 1D, both derived from the amino acid valine, were the most potent of the $N$-allylamide (1A-1C) and vinylbenzene (1D-1G) series with $44 \%$ and $36 \%$ displacement of DNSA, respectively. Again the bulkier compounds, in this case those with the amino acid side chains of leucine (1B and $\mathbf{1 E}$ ), phenylglycine (1F) and phenylalanine (1C and 1G), exhibited reduced bCA II affinity in comparison to the sterically smaller side chains.

As the bCA II screen was performed directly on the crude library, without isolation of the CM heterodimers 1A-1J, we needed to validate that the bCA II affinity was due to these heterodimers and not just the reduced presence of the bis-sulfonamide $\mathbf{2 a b}$. We proceeded to synthesize the trans isomers of the ester building block series $\mathbf{1 H - 1 J}$ as pure entities. A determination of the bCA II equilibrium dissociation constants (Ki's) was then carried out and results for affinities $\mathbf{2} \mathbf{a b}, \mathbf{2 a}, \mathbf{2} \mathbf{b}, \mathbf{1 H}, \mathbf{1 I}$ and $\mathbf{1 J}$ are presented in Table 1. Each of the pure compounds exhibited affinity for bCA II in the low-mid nanomolar range, with Ki's of 5.1, 4.9, 4.9, 9.3, 6.6 and $8.5 \mathrm{nM}$ for $\mathbf{2 a b}, \mathbf{2 a}, \mathbf{2 b}, \mathbf{1 H}, \mathbf{1 I}$ and $\mathbf{1 J}$, respectively. The relative order of Ki's was 2ab $\sim \mathbf{2 a} \sim \mathbf{1 H}>\mathbf{1 I}>\mathbf{1 J}>\mathbf{2 b}$. These results were in full agreement with the relative affinities determined from screening the library where $\mathbf{2 a b} \sim \mathbf{1 H}>\mathbf{1 I}>\mathbf{1 J}$ at $10 \mu \mathrm{M}$. This agreement, although with a representative number of building blocks, was consistent with the observed trend of bCA II affinity obtained when assaying the library without purification or clean up.

\subsection{Synthetic Chemistry}

The synthesis of $\mathbf{1}, \mathbf{2 a}, \mathbf{2 b}, \mathbf{1 I}$ (trans isomer) and the tertiary $N$-allylamide building blocks (AC) have been reported by ourselves elsewhere. ${ }^{25,29}$ Building block $\mathbf{H}$ was commercially available (Sigma-Aldrich, allyl acetate, catalogue number 18,524-8), while building blocks I and $\mathbf{J}$ were synthesized from allyl alcohol, and benzoic acid or $p$-phenyl benzoic acid, respectively as previously described in the literature. ${ }^{30,31} \mathrm{New}$ building blocks D-G were synthesized by standard peptide coupling conditions of the reagent $p$-vinylbenzoic acid with four different L-amino acid methyl esters using EDC and $\mathrm{HOBT}$ in $\mathrm{CH}_{2} \mathrm{Cl}_{2}$ at room temperature. Work-up involved partitioning the reaction mixture between $\mathrm{CH}_{2} \mathrm{Cl}_{2}$ and $\mathrm{K}_{2} \mathrm{CO}_{3}$; the $\mathrm{CH}_{2} \mathrm{Cl}_{2}$-soluble material was subjected to flash silica chromatography using EtOAc/Hexane, yields ranged from 18-53\%. The synthesis of 2ab proceeded by CM reaction of 1 using Grubbs second-generation catalyst in 1,2-DCE as solvent at $150{ }^{\circ} \mathrm{C}$ for $20 \mathrm{~min}$ in a 
microwave reactor, 29\% yield. Synthesis of authentic trans isomers of $\mathbf{1 H}$ and $\mathbf{1} \mathbf{J}$ proceeded in a similar fashion to that reported by us for $\mathbf{1 I} .^{25}$

\section{Conclusion}

This study has demonstrated that the application of fragment-based drug discovery to inhibitors of bCA II is effective utilizing a pre-equilibrated DCC strategy together with CM as the reversible reaction. Specifically, the results demonstrated that with appropriate control experiments confidence in the observed trend of bCA II affinity obtained when assaying the library without purification was indeed a reflection of actual bCA II affinity. This result is significant as synthesis and purification of CM products is typically cumbersome, and if it can be avoided at the early stage of the drug discovery timeline (which is where DCC typically is placed) then it is highly advantageous from the viewpoint of both cost and required effort. Finally, heterogeneous catalysis has not before been applied to DCC. Herein we have demonstrated the convenience and benefits of heterogenous catalysis (over homogeneous catalysis) to facilitate the reaction start-stop requirements for drug discovery applications of DCC: simple filtration to remove the catalyst (stop sequence), and addition/re-addition of catalyst (start sequence).

\section{Experimental}

\subsection{Chemistry}

All synthetic reagents and anhydrous solvents used were purchased from commercial sources. Grubbs first-generation catalyst was available as an immobilized reagent (Fluka catalogue number 91501, on a polystyrene support, loading $0.1 \mathrm{mmol} / \mathrm{g}$ ) while Grubbs secondgeneration catalyst was purchased from Sigma-Aldrich (catalogue number 569747). All solvents used for chromatography were Lab-Scan HPLC grade. Flash chromatography was performed on E. Merck Silica gel GF-60 grade silica (particle size $0.0400-0.063 \mathrm{~mm}$ ). Analytical thin-layer chromatography was performed on 0.25 E Merck silica-gel plates (60-F254). Analysis of TLC was conducted using standard short-wave UV, $5.0 \% \mathrm{v} / \mathrm{v}$ $\mathrm{H}_{2} \mathrm{SO}_{4} /$ Ethanol char, $\mathrm{KMnO}_{4}$ and ninhydrin stains, where appropriate. Reaction yields less than $<1$ g were purified with Varian ${ }^{\mathrm{TM}}$ mega bond elut solid-phase extraction columns (normal phase silica). NMR spectra were recorded at $25{ }^{\circ} \mathrm{C}$ on a Varian $400 \mathrm{MHz}$ Unity INOVA or Varian $200 \mathrm{MHz}$ Gemini spectrometer. The ${ }^{1} \mathrm{H}$ and ${ }^{13} \mathrm{C}$ chemical shifts were referenced to the solvent peak for DMSO- $d_{6}$ or $\mathrm{CDCl}_{3}$ at $\delta_{\mathrm{H}} 2.49$ and $\delta_{\mathrm{C}} 39.51$ or $\delta_{\mathrm{H}} 7.23$ and 
$\delta_{C} 77.00$, respectively. ESI MS were recorded on a Fisons VG platform quadrupole mass spectrometer with MassLynx data storage and management software. The mass spectrometer was operated in positive ion and negative ion modes, at cone voltages of \pm 30 to $\pm 45 \mathrm{eV}$. HRMS (ESI) were recorded on a Bruker Daltonics Apex III 47e FTICR mass spectrometer equipped with an Apollo ESI source.

\section{(2E,Z)-But-2-en-1,4-diyl-bis[(aminosulfonyl)benzoate] (2ab)}

To a solution of 1 (51 mg, $0.21 \mathrm{mmol})$ in 1,2-DCE $(1 \mathrm{~mL})$ in a pressure tube, sealed with a Teflon septum was added Grubbs second-generation catalyst (35 mg, 20 mol\%). The pressure tube was introduced to the centre of a CEM Discover microwave oven and then heated to 150 ${ }^{\circ} \mathrm{C}$ for 20 minutes. On completion of the heating cycle the reaction mixture was concentrated and purified by solid phase extraction on normal phase silica sorbent, eluted with $\mathrm{CH}_{2} \mathrm{Cl}_{2} /$ Methanol (3:1, v/v) to generate $2 \mathbf{a b}$ (14 mg, yield 29\%) as a brown syrup. Characterization data was consistent with the trans product $2 \mathbf{a}^{25}{ }^{1} \mathrm{H}$ NMR (200 $\mathrm{MHz}, \mathrm{CDCl}_{3}$, ppm): $\delta$ 8.13-8.10 (m, 4H, ArH), 7.94-7.92 (m, 4H, ArH), 7.53 (br s, 4H, $\mathrm{NH}_{2}$ ), 5.94-5.92 (m, 2H, $=\mathrm{CH}$ ), 5.01-5.00 (m, 4H, $\left.\mathrm{CH}_{2}\right) ;{ }^{13} \mathrm{C}$ NMR (100 MHz, $\left.\mathrm{CDCl}_{3}, \mathrm{ppm}\right): \delta 165.3$ (CO), 148.8 (=CH), 132.9, 130.6, 128.9, $126.8(\mathrm{ArCH}), 61.8\left(\mathrm{CH}_{2}\right)$; ESI MS: $\mathrm{m} / \mathrm{z}[\mathrm{M}-\mathrm{H}]^{-} 453.0$.

\section{Synthesis of methyl-3-methyl-2-[(4-vinylbenzoyl)amino]butanoate $\quad$ (D) as a representative of building blocks D-G.}

A suspension of 4-vinylbenzoic acid (100 mg, $0.67 \mathrm{mmol})$, EDC (1.29 g, $0.67 \mathrm{mmol}$ ) and HOBT (72 mg, $0.54 \mathrm{mmol}$ ) in dry $\mathrm{CH}_{2} \mathrm{Cl}_{2}(2 \mathrm{~mL})$ was prepared and left stirring at room temperature for $3 \mathrm{~h}$. L-Valine methyl ester hydrochloride (0.224 g, $1.34 \mathrm{mmol})$ and DIPEA ( $0.864 \mathrm{~g}, 6.7 \mathrm{mmol})$ were added and the reaction mixture was stirred a further $18 \mathrm{~h}$. The reaction mixture was diluted with $\mathrm{CH}_{2} \mathrm{Cl}_{2}(5 \mathrm{~mL})$, washed with $2 \mathrm{M} \mathrm{K}_{2} \mathrm{CO}_{3}(5 \mathrm{~mL})$ and saturated brine ( $2 \times 5 \mathrm{~mL}$ ). The organic phase was dried over $\mathrm{MgSO}_{4}$ and concentrated to afford a crude yellow oil which was purified by solid-phase extraction on normal phase silica sorbent (eluted with EtOAc/Hexane, 1:2, v/v) to give D in 53\% yield (92 mg), as a white solid. ${ }^{1} \mathrm{H}$ NMR (200 MHz, $\left.\mathrm{CDCl}_{3}, \mathrm{ppm}\right): \delta$ 7.98-7.56 (m, 2H, ArH), 7.48-7.44 (m, 2H, ArH), 6.74 (dd, $1 \mathrm{H},{ }^{3} J_{m a}=17.6 \mathrm{~Hz},{ }^{3} J_{m x}=11.0 \mathrm{~Hz},=\mathrm{CH}$ ), 6.69 (br s, $\left.1 \mathrm{H}, \mathrm{NH}\right), 5.87-5.79(\mathrm{~m}, 1 \mathrm{H}$, $\left.{ }^{3} J_{a m}=17.6 \mathrm{~Hz},{ }^{3} J_{a x}=0.8 \mathrm{~Hz},=\mathrm{CH}_{2}\right), 5.35\left(\mathrm{dd}, 1 \mathrm{H},{ }^{3} J_{x m}=11.0 \mathrm{~Hz},{ }^{3} J_{x a}=0.8 \mathrm{~Hz},=\mathrm{CH}_{2}\right), 4.78$ (dd, $1 \mathrm{H}, J=5.2 \mathrm{~Hz}, \alpha \mathrm{CH}$ ), 3.77 (s, 3H, $\mathrm{OCH}_{3}$ ), 2.35-2.22 (m, 1H, $\beta \mathrm{CH}$ ), 1.02 (d, $3 \mathrm{H}, J=7.4$ $\mathrm{Hz}, \gamma^{\prime} \mathrm{CH}_{3}$ ), 0.98 (d, $3 \mathrm{H}, J=7.4 \mathrm{~Hz}, \gamma \mathrm{CH}_{3}$ ); ${ }^{13} \mathrm{C}$ NMR (50 MHz, $\left.\mathrm{CDCl}_{3}, \mathrm{ppm}\right): \delta 172.8$ $\left(\mathrm{COCH}_{3}\right), 167.0(\mathrm{CONH}), 141.0,136.1,133.4,127.6,126.5(\mathrm{ArCH},=\mathrm{CH}), 116.2\left(=\mathrm{CH}_{2}\right)$, 
$57.7\left(\mathrm{OCH}_{3}\right), 52.5(\alpha \mathrm{CH}), 31.9(\beta \mathrm{CH})$ 19.3, $18.3\left(\gamma, \gamma^{\prime} \mathrm{CH}_{3}\right)$; ESI MS: $m / z 262.4[\mathrm{M}+\mathrm{H}]^{+}$, 284.1 [M+Na] ${ }^{+}$; HRMS (ESI) 284.1249. Calculated for $\mathrm{C}_{15} \mathrm{H}_{19} \mathrm{~N}_{1} \mathrm{O}_{3} \cdot \mathrm{Na}^{+}$: 284.1257.

\section{Methyl-4-methyl-2-[(4-vinylbenzoyl)amino]pentanoate (E)}

Preparation from L-leucine methyl ester hydrochloride. (Yield 18\%). ${ }^{1} \mathrm{H}$ NMR (200 MHz, $\mathrm{CDCl}_{3}, \mathrm{ppm}$ ): $\delta$ 7.77-7.73 (m, 2H, ArH), 7.45-7.39 (m, 2H, ArH), 6.82-6.79 (br s, $1 \mathrm{H}, \mathrm{NH}$ ), 6.79-6.65 (dd, $\left.1 \mathrm{H},{ }^{3} J_{m a}=17.4 \mathrm{~Hz},{ }^{3} J_{m x}=10.4 \mathrm{~Hz},=\mathrm{CH}\right), 5.81\left(\mathrm{~d}, 1 \mathrm{H},{ }^{3} J_{a m}=17.4 \mathrm{~Hz},=\mathrm{CH}_{2}\right.$ ), $5.34\left(\mathrm{~d}, 1 \mathrm{H},{ }^{3} J_{x m}=10.4 \mathrm{~Hz},=\mathrm{CH}_{2}\right), 4.91-4.80(\mathrm{~m}, 1 \mathrm{H}, \alpha \mathrm{CH}), 3.76\left(\mathrm{~s}, 3 \mathrm{H}, \mathrm{OCH}_{3}\right), 1.79-1.62$ (m, 3H, $\beta \mathrm{CH}_{2}, \gamma \mathrm{CH}$ ), 0.99 (d, $3 \mathrm{H}, J=7.4 \mathrm{~Hz}, \delta^{`} \mathrm{CH}_{3}$ ), 0.95 (d, $\left.3 \mathrm{H}, J=7.4 \mathrm{~Hz}, \delta \mathrm{CH}_{3}\right) ;{ }^{13} \mathrm{C}$ NMR (50 MHz, $\left.\mathrm{CDCl}_{3}, \mathrm{ppm}\right): \delta 174.0\left(\mathrm{COCH}_{3}\right), 166.9(\mathrm{CONH}), 141.0,136.1,133.1,127.6$, 126.4, $(\mathrm{ArCH},=\mathrm{CH}), 116.2\left(=\mathrm{CH}_{2}\right), 52.6,51.4\left(\alpha \mathrm{CH}, \mathrm{OCH}_{3}\right), 42.0\left(\beta \mathrm{CH}_{2}\right), 25.3(\gamma \mathrm{CH})$, 23.1, $22.3\left(\delta, \delta^{\circ} \mathrm{CH}_{3}\right)$; ESI MS: $m / z$ 276.1 [M+H] $]^{+}, 298.7[\mathrm{M}+\mathrm{Na}]^{+}$; HRMS (ESI) 298.1396. Calculated for $\mathrm{C}_{16} \mathrm{H}_{21} \mathrm{~N}_{1} \mathrm{O}_{3} \cdot \mathrm{Na}^{+}$: 298.1404.

\section{Methyl-phenyl[(4-vinylbenzoyl)amino]acetate (F)}

Preparation from L-phenylglycine methyl ester hydrochloride. (Yield 27\%). ${ }^{1} \mathrm{H}$ NMR (200MHz, $\left.\mathrm{CDCl}_{3}, \mathrm{ppm}\right): \delta$ 7.83-7.79 (m, 2H, ArH), 7.51-7.33 (m, 7H, ArH), 7.30 and 7.27 (br s, $1 \mathrm{H}, \mathrm{NH}), 6.74\left(\mathrm{dd}, 1 \mathrm{H},{ }^{3} J_{m a}=17.6 \mathrm{~Hz},{ }^{3} J_{m x}=10.8 \mathrm{~Hz},=\mathrm{CH}\right), 5.84\left(\mathrm{~d}, 1 \mathrm{H},{ }^{3} J_{a m}=17.6\right.$ $\left.\mathrm{Hz},=\mathrm{CH}_{2}\right), 5.81(\mathrm{~d}, 1 \mathrm{H}, J=7 \mathrm{~Hz}, \alpha \mathrm{CH}), 5.37$ (d, $\left.1 \mathrm{H},{ }^{3} J_{x m}=10.8 \mathrm{~Hz},=\mathrm{CH}_{2}\right), 3.77(\mathrm{~s}, 3 \mathrm{H}$, $\left.\mathrm{OCH}_{3}\right) ;{ }^{13} \mathrm{C} \mathrm{NMR}\left(50 \mathrm{MHz}, \mathrm{CDCl}_{3}, \mathrm{ppm}\right): \delta 171.7\left(\mathrm{COCH}_{3}\right), 166.5(\mathrm{CONH}), 141.2,136.7$, 136.1, 132.8, 130.6, 129.2, 128.8, 127.8, 127.6, $126.5(\mathrm{ArCH},=\mathrm{CH}), 116.4\left(=\mathrm{CH}_{2}\right), 57.1$ $\left(\mathrm{OCH}_{3}\right), 53.7(\alpha \mathrm{CH})$; ESI MS: $m / z$ 296.7 [M+H] $]^{+}, 318.4[\mathrm{M}+\mathrm{Na}]^{+}$; HRMS (ESI) 318.1091. Calculated for $\mathrm{C}_{18} \mathrm{H}_{17} \mathrm{~N}_{1} \mathrm{O}_{3} \cdot \mathrm{Na}^{+}$: 318.1101.

\section{Methyl-3-phenyl-2-[(4-vinylbenzoyl)amino]propanoate (G)}

Preparation from L-phenylalanine methyl ester hydrochloride. (Yield 32\%). ${ }^{1} \mathrm{H}$ NMR (200MHz, $\mathrm{CDCl}_{3}$, ppm): $\delta$ 7.73-7.69 (m, 2H, ArH), 7.45-7.41 (m, 2H, ArH), 7.31-7.14 (m, 5H, ArH), 6.82 and 6.78 (br s, $1 \mathrm{H}, \mathrm{NH}), 6.73$ (dd, $1 \mathrm{H},{ }^{3} J_{m a}=17.6 \mathrm{~Hz},{ }^{3} J_{m x}=11.0 \mathrm{~Hz},=\mathrm{CH}$ ), $5.84\left(\mathrm{~d}, 1 \mathrm{H},{ }^{3} J_{a m}=17.4 \mathrm{~Hz},=\mathrm{CH}_{2}\right), 5.50\left(\mathrm{~d}, 1 \mathrm{H},{ }^{3} J_{x m}=10.8 \mathrm{~Hz},=\mathrm{CH}_{2}\right), 5.15-5.06(\mathrm{~m}, 1 \mathrm{H}$, $\alpha \mathrm{CH}$ ), 3.76 (s, $\left.3 \mathrm{H}, \mathrm{OCH}_{3}\right), 3.30-3.24\left(\mathrm{~m}, 2 \mathrm{H}, \mathrm{CH}_{2} \mathrm{Ph}\right) ;{ }^{13} \mathrm{C} \mathrm{NMR}\left(50 \mathrm{MHz}, \mathrm{CDCl}_{3}, \mathrm{ppm}\right): \delta$ $172.3\left(\mathrm{COCH}_{3}\right), 166.7(\mathrm{CONH}), 141.1,136.1,133.1,129.5,128.8,127.6,127.4,126.5$, $(\mathrm{ArCH},=\mathrm{CH}), 116.3\left(=\mathrm{CH}_{2}\right), 53.9,53.7\left(\alpha \mathrm{CH}, \mathrm{OCH}_{3}\right), 38.1\left(\mathrm{CH}_{2} \mathrm{Ph}\right) ; \mathrm{ESI} \mathrm{MS}: \mathrm{m} / \mathrm{z} 310.1$ $[\mathrm{M}+\mathrm{H}]^{+}, 332.5[\mathrm{M}+\mathrm{Na}]^{+}$; HRMS (ESI) 332.1261. Calculated for $\mathrm{C}_{19} \mathrm{H}_{19} \mathrm{~N}_{1} \mathrm{O}_{3} \cdot \mathrm{Na}^{+}: 332.1258$.

\section{Synthesis of (2E)-4-(acyloxy)but-2-enyl-4-(aminosulfonyl)benzoate (1H)}

To a solution of (2E)-butene-1,4-diol (0.5 g, $5.7 \mathrm{mmol})$ in pyridine $(10 \mathrm{~mL})$ was added acetic anhydride $(0.756 \mathrm{~g}, 7.4 \mathrm{mmol})$ dropwise over $6 \mathrm{~h}$. The reaction was stirred at room 
temperature for $24 \mathrm{~h}$ and then concentrated. The residue was redissolved in $\mathrm{CH}_{2} \mathrm{Cl}_{2}(25 \mathrm{~mL})$, washed with $1 \mathrm{~N} \mathrm{HCl}(2 \times 20 \mathrm{~mL})$, saturated $\mathrm{NaHCO}_{3}(20 \mathrm{~mL})$ and saturated brine $(20 \mathrm{~mL})$. The organic phase was dried over $\mathrm{MgSO}_{4}$ and evaporated to afford the mono-acetyl intermediate ( $0.70 \mathrm{~g}$, yield $95 \%)$, which was used without further purification. To a mixture of this intermediate $(100 \mathrm{mg}, 0.77 \mathrm{mmol})$ in DMF $(2.5 \mathrm{~mL})$ were added 4carboxybenzensulfonamide (78 mg, $0.39 \mathrm{mmol}$ ), 1,3-dicyclohexylcarbodiimide (80 mg, 0.39 mmol) and DMAP (25 mg, $0.21 \mathrm{mmol}$ ). The solution was stirred at room temperature for 18 h. The reaction mixture was filtered through Celite and the filtrate diluted with EtOAc (25 $\mathrm{mL})$, washed with $1 \mathrm{~N} \mathrm{HCl}(2 \times 25 \mathrm{~mL})$ and saturated brine $(20 \mathrm{~mL})$. The organic phase was dried over $\mathrm{MgSO}_{4}$ and evaporated. Purification by solid-phase extraction on normal phase silica sorbent (eluted with Hexane/EtOAc, 1:1, v/v) was carried out to generate $\mathbf{1 H}$ (73 mg, $60 \%$ yield) as a white solid. ${ }^{1} \mathrm{H}$ NMR (400 $\left.\mathrm{MHz} \mathrm{CDCl}_{3}, \mathrm{ppm}\right): \delta$ 8.16-8.13 (m, 2H, ArH), 7.99-7.96 (m, 2H, ArH), 5.90-5.78 (m, 2H, =CH), 5.16 (br s, 2H, $\mathrm{NH}_{2}$ ), 4.96-4.94 (m, 2H, $\mathrm{CH}_{2}$ ), 4.74-4.72 (m, 2H, $\mathrm{CH}_{2}$ ), 2.06 (s, 3H, $\left.\mathrm{CH}_{3}\right) ;{ }^{13} \mathrm{C}$ NMR (100 MHz, $\left.\mathrm{CDCl}_{3}, \mathrm{ppm}\right): \delta 171.0$ (CO), 165.0 (CO), $146.5\left(\mathrm{OCH}_{2} \mathrm{CH}=\mathrm{CH}\right), 133.9\left(\mathrm{OCH}_{2} \mathrm{CH}=\mathrm{CH}\right), 130.6,129.0,127.7,126.7$ (ArCH), $61.7\left(\mathrm{CH}_{2} \mathrm{CH}=\right), 60.2\left(\mathrm{CH}_{2} \mathrm{CH}=\right), 21.1\left(\mathrm{CH}_{3}\right)$; ESI MS: m/z [M-H] 311.91; HRMS (ESI) 312.0544. Calculated for $\mathrm{C}_{13} \mathrm{H}_{14} \mathrm{~N}_{1} \mathrm{O}_{6} \mathrm{~S}_{1}{ }^{-}: 312.0547$.

\section{Synthesis of (2E)-4-(biphenyloxy)but-2-enyl-4-(aminosulfonyl)benzoate (1J)}

Biphenylcarbonyl chloride $(0.125 \mathrm{~g}, 0.575 \mathrm{mmol})$ was added portionwise over $2 \mathrm{~h}$ to a solution of (2E)-butene-1,4-diol (1.20 g, $2.3 \mathrm{mmol})$ in pyridine $(5 \mathrm{~mL})$. The solution was stirred at room temperature for $72 \mathrm{~h}$ and then concentrated. The residue was redissolved in $\mathrm{CH}_{2} \mathrm{Cl}_{2}(25 \mathrm{~mL})$, washed with $1 \mathrm{~N} \mathrm{HCl}(2 \times 20 \mathrm{~mL})$, saturated $\mathrm{NaHCO}_{3}(20 \mathrm{~mL})$ and saturated brine (20 mL). The organic phase was dried over $\mathrm{MgSO}_{4}$ and evaporated to afford the monobiphenyl intermediate (0.142 g, yield 92\%), which was used in the next step without purification. To a mixture of this intermediate $(0.142 \mathrm{~g}, 0.53 \mathrm{mmol})$ in DMF $(5 \mathrm{~mL})$ were added 4-carboxybenzensulfonamide (0.230 g, $1.15 \mathrm{mmol})$, 1,3-dicyclohexylcarbodiimide (0.237 g, $1.15 \mathrm{mmol})$ and DMAP (25 $\mathrm{mg}, 0.17 \mathrm{mmol})$. The reaction was stirred at room temperature for $8 \mathrm{~h}$ then filtered through Celite and the filtrate concentrated to give a clear oil. Purification by solid-phase extraction on normal phase silica sorbent (eluted with $\mathrm{CH}_{2} \mathrm{Cl}_{2} /$ Methanol, 20:1, v/v) was carried out to generate $\mathbf{1 J}$ (29 mg, yield 11\%) as a white solid. ${ }^{1} \mathrm{H}$ NMR (400 MHz, DMSO- $\left.d_{6}, \mathrm{ppm}\right): \delta$ 8.13-8.11 (m, 2H, ArH), 8.03-8.01 (m, 2H, ArH), 7.94-7.92 (m, 2H, ArH), 7.81-7.79 (m, 2H, ArH), 7.73-7.71 (m, 2H, ArH), 7.51-7.41 (m, 5H, ArH, $\left.\mathrm{NH}_{2}\right), 5.95-5.94(\mathrm{~m}, 2 \mathrm{H},=\mathrm{CH}), 5.03-5.00\left(\mathrm{~m}, 4 \mathrm{H}, \mathrm{CH}_{2}\right) ;{ }^{13} \mathrm{C} \mathrm{NMR}(100 \mathrm{MHz}$, 
$\left.\mathrm{CDCl}_{3}, \mathrm{ppm}\right): \delta 166.0(\mathrm{CO}), 163.0(\mathrm{CO}), 148.8\left(\mathrm{OCH}_{2} \mathrm{CH}=\mathrm{CH}\right), 145.5\left(\mathrm{OCH}_{2} \mathrm{CH}=\mathrm{CH}\right)$, 132.9, 130.6, 130.5, 129.8, 129.3, 129.1, 129.0, 128.7, 127.7, 126.7 ( $\mathrm{ArCH}), 61.8\left(\mathrm{CH}_{2} \mathrm{CH}=\right)$, $61.3\left(\mathrm{CH}_{2} \mathrm{CH}=\right)$; ESI MS: $\mathrm{m} / \mathrm{z}[\mathrm{M}-\mathrm{H}]^{-}$450.02; HRMS (ESI) 450.1020. Calculated for $\mathrm{C}_{24} \mathrm{H}_{20} \mathrm{~N}_{1} \mathrm{O}_{6} \mathrm{~S}_{1}{ }^{-}: 450.1016$.

\subsection{General procedure for preparation of pDCLs by CM}

To a solution of each building block (25 mM) for self-CM or 1 (25 mM) and each of A-J (25 $\mathrm{mM}, 1$ eq.) in 1,2-DCE (0.1 mL) was added immobilized Grubbs first-generation catalyst (20 mol\%). The reaction mixture was stirred at $50{ }^{\circ} \mathrm{C}$ for $24 \mathrm{~h}$ before removal of the catalyst by filtration and analysis by ESI MS. ESI MS spectra were recorded on a Micromass VG Platform 2, single quadrupole instrument fitted with a linear electrospray source. The source was heated to $90{ }^{\circ} \mathrm{C}$ and the sampling cone voltage was $30 \mathrm{eV}$. Samples were prepared by dilution of the pDCL reaction with $\mathrm{CH}_{3} \mathrm{CN}$ (1/10 dilution). Samples were introduced into the mass spectrometer source with an LC pump (Shimatzu LC-9A and mixing valve FCV-9AL.) at a rate of $1.0 \mathrm{~mL} / \mathrm{min}$ in $\mathrm{CH}_{3} \mathrm{CN} / \mathrm{H}_{2} \mathrm{O} 80 \% / 20 \%$. Scanning was performed from 100 to 2000 $\mathrm{m} / \mathrm{z}$ over $4 \mathrm{~s}$ and multiple scans were summed to obtain the final spectrum, which was processed using MassLynx V 3.4 software. Sample preparation for the bCA II enzyme assay was performed by serial dilution of the pDCL with water.

\subsection{Biological assay}

Compounds 2ab, 1H, 1I, 1J and all pDCL reactions were assessed for their ability to inhibit the binding of DNSA to bCA II (CA II from bovine erythrocytes, Sigma-Aldrich, catalogue number C2522, lot number 044K6064). Enzyme assays were carried out in 96-well microtitre plates (Nunc F96) in an assay volume of $200 \mu \mathrm{L}$. Each assay contained bCA II (140 nM); DNSA (3 $\mu \mathrm{M}$, equals 10 times the Kd value), incubation buffer (phosphate buffer, $\mathrm{pH} 7.2$ ) and test compound in DMSO with triplicate determinations (at 15 concentrations for compound Ki determination or at $1 \mu \mathrm{M}$ and $10 \mu \mathrm{M}$ final concentration for pDCL screening). The final DMSO concentration in the assay was $1 \%$, this concentration of DMSO did not decrease control binding. The assay was incubated for $4 \mathrm{~h}$ at $25{ }^{\circ} \mathrm{C}$. Fluorescence measurements were carried out on a Varian Cary-Eclipse spectrophotometer in fluorescence mode using a multiwell plate reader at $25{ }^{\circ} \mathrm{C}$ (excitation wavelength of $290 \mathrm{~nm}$, emission wavelength of $460 \mathrm{~nm}$ ). Known compounds (acetazolamide and sulfanilamide) were used to characterize this assay procedure. Data were fitted to a sigmoidal dose-response equation 
using nonlinear regression analysis (GraphPad Prism V4, San Diego, Califonia, USA). The measurement of the Kd of DNSA was determined by titrating bCA II (140 nM in pH 7.2 phosphate buffer) with DNSA (100 nM - $3500 \mathrm{nM}$ ) and monitoring the fluorescence as described above. Data were fitted to an equilibrium one-site binding model using nonlinear regression analysis. The Kd of DNSA was calculated as $0.3 \mu \mathrm{M}$ and is comparable with literature. ${ }^{18}$ The Ki of sulfonamide inhibitors was calculated using the Kd of DNSA and the Cheng-Prussof equation. ${ }^{32}$

\section{Acknowledgements -}

The authors thank the Australian Research Council (Grant numbers F00103312 and DP0343419) and Griffith University for research funding.

\section{References -}

1. Lehn, J.-M. Chem. Eur. J. 1999, 5, 2455.

2. Rowan, S. J.; Cantrill, S. J.; Cousins, G. R. L.; Sanders, J. K. M.; Stoddart, J. F. Angew. Chem. Int. Ed. 2002, 41, 898.

3. Ramström, O.; Lehn, J.-M. ChemBioChem 2000, 1, 41.

4. Bunyapaiboonsri, T.; Ramström, O.; Lohmann, S.; Lehn, J.-M.; Peng, L.; Goeldner, M. ChemBioChem 2001, 2, 438.

5. Huc, I.; Lehn, J.-M. Proc. Natl. Acad. Sci. USA 1997, 94, 2106.

6. Nguyen, R.; Huc, I. Angew. Chem. Int. Ed. 2001, 40, 1774.

7. Hochgürtel, M.; Kroth, H.; Piecha, D.; Hofmann, M. W.; Nicolau, C.; Krause, S.; Schaaf, O.; Sonnenmoser, G.; Eliseev, A. V. Proc. Natl. Acad. Sci. USA 2002, 99, 3382.

8. Hochgürtel, M.; Biesinger, R.; Kroth, H.; Piecha, D.; Hofmann, M. W.; Krause, S.; Schaaf, O.; Nicolau, C.; Eliseev, A. V. J. Med. Chem. 2003, 46, 356.

9. Congreve, M.S.; Davis, D.J.; Devine, L.; Granata, C.; O'Reilly, M.; Wyatt, P.G.; Jhoti, H. Angew. Chem. Int. Ed. 2003, 42, 4479.

10. Bunyapaiboonsri, T.; Ramström, H.; Ramström, O.; Haiech, J.; Lehn, J.-M. J. Med. Chem. 2003, 46, 5803.

11. Hong, L.; Williams, P.; Micklefield, J.; Gardiner, J. M.; Stephens, G. Tetrahedron 2004, 60, 753.

12. Zameo, S.; Vauzeilles, B.; Beau, J.-M. Angew. Chem. Int. Ed. 2005, 44, 965. 
13. Pei, Z.; Larsson, R.; Aastrup, T.; Anderson, H.; Ramström, O. Abstracts of Papers, 230th ACS National Meeting, Washington, DC, United States, 2005.

14. Ramström, O.; Lohmann, S.; Bunyapaiboonsri, T.; Lehn, J.-M. Chemistry - A European Journal 2004, 10, 1711.

15. Erlanson, D. A.; McDowell, R. S.; O’Brien, T. J. Med. Chem. 2004, 47, 3463.

16. Nicolaou, K. C.; Hughes, R.; Cho, S. Y.; Winssinger, N.; Smethurst, C.; Labischinski, H.; Endermann, R. Angew. Chem. Int. Ed. 2000, 39, 3823.

17. Supuran, C. T.; Scozzafava, A. Curr. Med. Chem. - Imun., Endoc. \& Metab. Agents. 2001, 1, 61.

18. Pastorekova, S.; Parkkila, S.; Pastorek, J.; Supuran, C. T. J. Enz. Inhib. Med. Chem. 2004, 19, 199.

19. Scozzafava, A.; Owa, T.; Mastrolorenzo, A.; Supuran, C. T. Curr. Med. Chem. 2003, 10, 925.

20. Pastorekova, S.; Casini, A.; Scozzafava, A.; Vullo, D.; Pastorek, J.; Supuran, C. T. Bioorg. Med. Chem. Lett. 2004, 14, 869.

21. Supuran, C. T. Expert Opin. Investig. Drugs. 2003, 12, 283.

22. Grubbs, R. H.; Chang, S. Tetrahedron 1998, 54, 4413.

23. Grubbs, R. H. Tetrahedron 2004, 60, 7117.

24. Chatterjee, A. K.; Choi, T.-L.; Sanders, D. P.; Grubbs, R. H. J. Am. Chem. Soc. 2003, 125, 11360.

25. Poulsen, S.-A.; Bornaghi, L. F.; Healy, P. C. Bioorg. Med. Chem. Lett. 2005, 15, 5429.

26. Sigal, G. B.; Whitesides, G. M. Bioorg. Med. Chem. Lett. 1996, 6, 559.

27. Chen, R. F.; Kernohan, J. C. J. Biol. Chem. 1967, 242, 5813.

28. Poulsen, S.-A.; Davis, R. D.; Keys, T. G. Bioorg. Med. Chem. Accepted 16 August 2005. DOI: 10.1016/j.bmc.2005.08.030.

29. Poulsen, S.-A.; Bornaghi, L. F. Tetrahedron Lett. 2005, 46, 7389.

30. Guo, Q.; Miyaji, T.; Hara, R.; Shen, B.; Takahashi, T. Tetrahedron 2002, 58, 7327.

31. Crosignani, S.; Gonzales, J.; Swinnen, D. Org. Lett. 2004, 6, 4579.

32. Cheng, Y.-C.; Prusoff, W. H. Biochem. Pharmacol. 1973, 22, 3099. 
Table 1. bCA II enzyme binding assay results for $\mathbf{1}, \mathbf{2 a b}, \mathbf{2 a}, \mathbf{2 b}$ and $\mathbf{1 H}-\mathbf{1 J}$ and standard compounds expressed as $\mathrm{Ki}$ in $\mathrm{nM}$.

\begin{tabular}{cc}
\hline Compound & bCA II Ki ${ }^{a}\left(\mathrm{R}^{2}\right)$ \\
\hline $\mathbf{1}$ & $8.6(0.97)$ \\
$\mathbf{2 a b}$ & $5.1(0.97)$ \\
$\mathbf{2 a}$ & $4.9(0.97)$ \\
$\mathbf{2 b}$ & $9.3(0.98)$ \\
$\mathbf{1 H}$ & $4.9(0.96)$ \\
$\mathbf{1 I}$ & $6.6(0.98)$ \\
$\mathbf{1 J}$ & $8.5(0.95)$ \\
acetazolamide & $6.9(0.96)$ \\
sulfanilamide & $1690(0.97)$
\end{tabular}

$a_{\mathrm{bCA}}$ II binding data utilizing competitive displacement of DNSA from bCA II, experiments performed in triplicate. Kd of DNSA was $0.3 \mu \mathrm{M}$. 
Figure 1.<smiles></smiles>

acetazolamide<smiles>CCOc1ccc2nc(S(N)(=O)=O)sc2c1</smiles>

ethoxazolamide<smiles>CC(=O)N=c1sc(S(N)(=O)=O)nn1C</smiles>

methazolamide<smiles>NS(=O)(=O)c1cc(Cl)c(Cl)c(S(N)(=O)=O)c1</smiles>

dichlorophenamide<smiles>CCN[C@H]1C[C@H](CCOC)S(=O)(=O)c2sc(S(N)(=O)=O)cc21</smiles>

brinzolamide<smiles>CCN[C@H]1C[C@@H](C)S(=O)(=O)c2sc(S(N)(=O)=O)cc21</smiles>

dorzolamide<smiles>NS(=O)(=O)c1ccc(S(=O)(=O)Nc2cccc3c(Cl)c[nH]c23)cc1</smiles>

indisulam 
Figure 2.

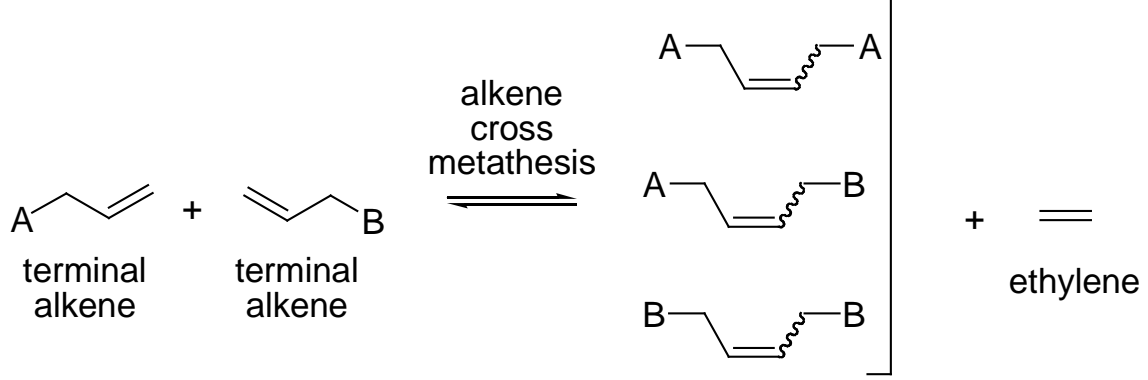

alkenes (cis/trans) 
Figure 3.

A

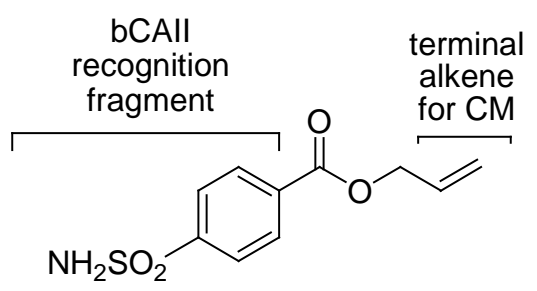

1

B<smiles>C=CCN(C(=O)c1ccccc1)[C@@H](C(C)=O)C(C)C</smiles>

A<smiles>[B]C(C)C[C@H](C(=O)OC)N(CC=C)C(=O)c1ccccc1</smiles><smiles>C=CCN(C(=O)c1ccccc1)[C@@H](Cc1ccccc1)C(=O)OC</smiles>

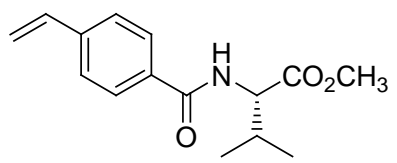

D<smiles>C=CCOC(C)=O</smiles>

H<smiles>C=Cc1ccc(C(=O)N[C@@H](CC(C)C)C(=O)OC)cc1</smiles>

E<smiles>C=CCOC(=O)c1ccccc1</smiles><smiles>C=Cc1ccc(C(=O)N[C@H](C(C)=O)c2ccccc2)cc1</smiles>

F<smiles>C=CCOC(=O)c1ccc(-c2ccccc2)cc1</smiles>

C<smiles>NS(=O)(=O)c1ccc(C(=O)OCC=CCOC(=O)c2ccc(S(N)(=O)=O)cc2)cc1</smiles>

$2 a b$<smiles>NS(=O)(=O)c1ccc(C(=O)OC/C=C/COC(=O)c2ccc(S(N)(=O)=O)cc2)cc1</smiles>

$2 a$<smiles>NS(=O)(=O)c1ccc(C(=O)OC/C=C\COC(=O)c2ccc(S(N)(=O)=O)cc2)cc1</smiles>

2b 
Figure 4.

A

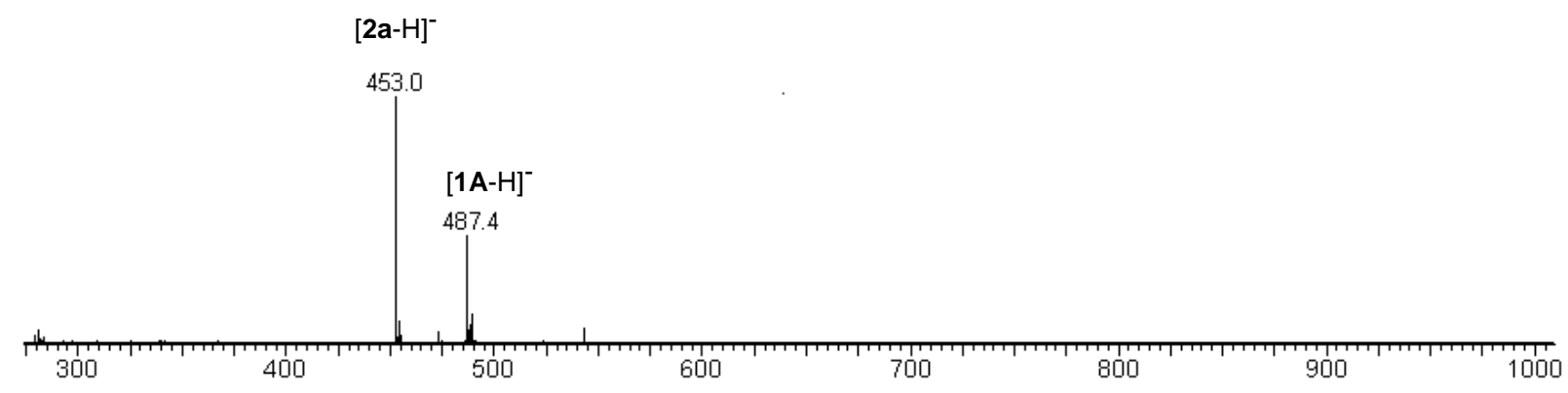

B

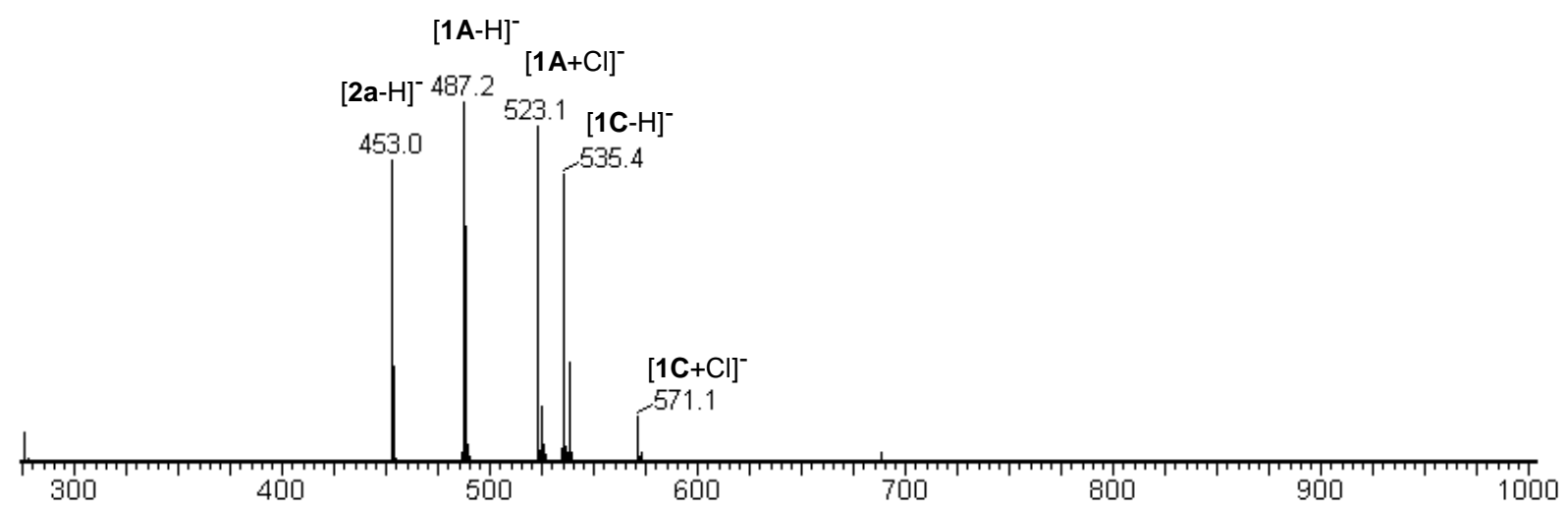


Figure 5.

A<smiles>[R]C(C(=O)OC)N(CC=CCN(C(=O)c1ccccc1)C([R])c1ccccc1)C(=O)OC</smiles>

$$
\begin{aligned}
& \mathrm{R}=\mathrm{iPr}=\mathrm{AA} \\
& \mathrm{R}=\mathrm{iBu}=\mathrm{BB} \\
& \mathrm{R}=\mathrm{CH}_{2} \mathrm{Ph}=\mathrm{CC}
\end{aligned}
$$<smiles>[R]C(NC(=O)c1ccc(C=Cc2ccc(C(=O)NC([R])C(C)=O)cc2)cc1)C(C)=O</smiles>

$$
\begin{aligned}
& \mathrm{R}=\mathrm{iPr}=\mathbf{D D} \\
& \mathrm{R}=\mathrm{iBu}=\mathbf{E E} \\
& \mathrm{R}=\mathrm{Ph}=\mathbf{F F} \\
& \mathrm{R}=\mathrm{CH}_{2} \mathrm{Ph}=\mathbf{G G}
\end{aligned}
$$<smiles>[R]C(=O)OCC=CCOC([R])=O</smiles>

$$
\begin{aligned}
& \mathrm{R}=\mathrm{CH}_{3}=\mathbf{H H} \\
& \mathrm{R}=\mathrm{Ph}=\mathbf{I I} \\
& \mathrm{R}=\mathrm{biPh}=\mathbf{J} \mathbf{J}
\end{aligned}
$$

$\mathbf{B}^{a}$

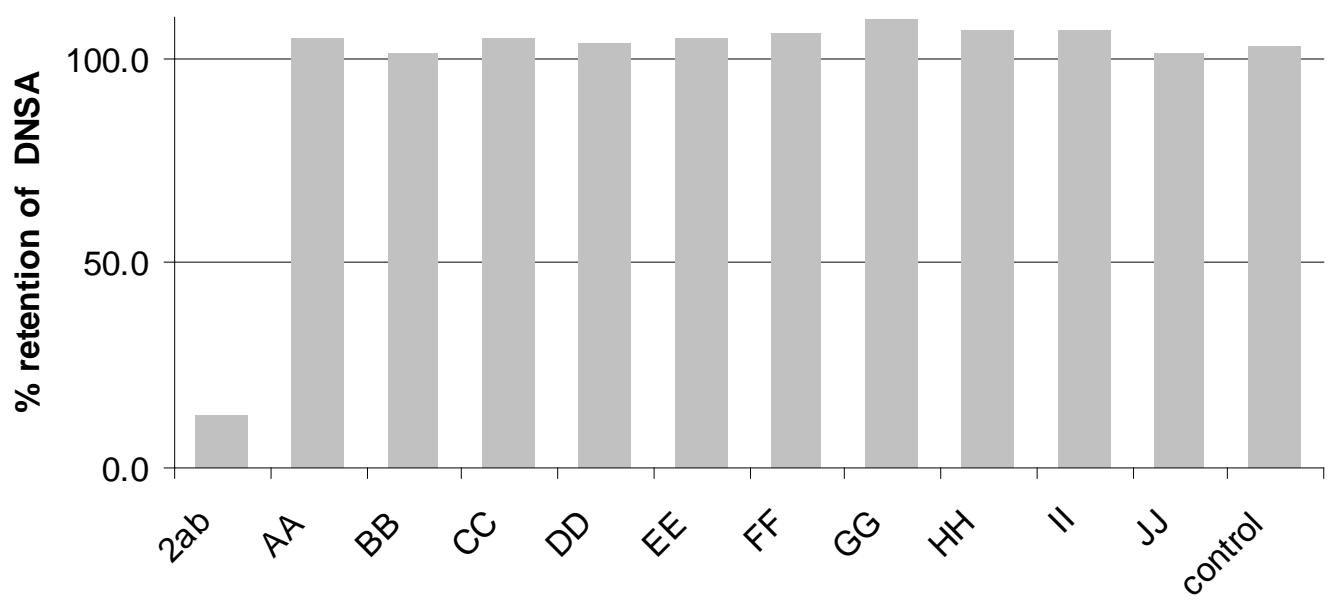

pDCL product, $10 \mu \mathrm{M}$

${ }^{a}$ Control experiment is assay result from immobilized metathesis catalyst only. 
Figure 6.

A

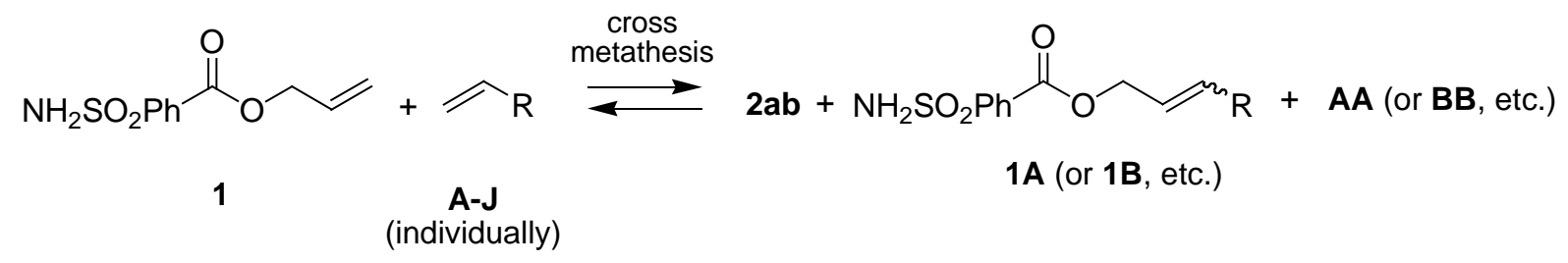

$\mathbf{B}^{a}$

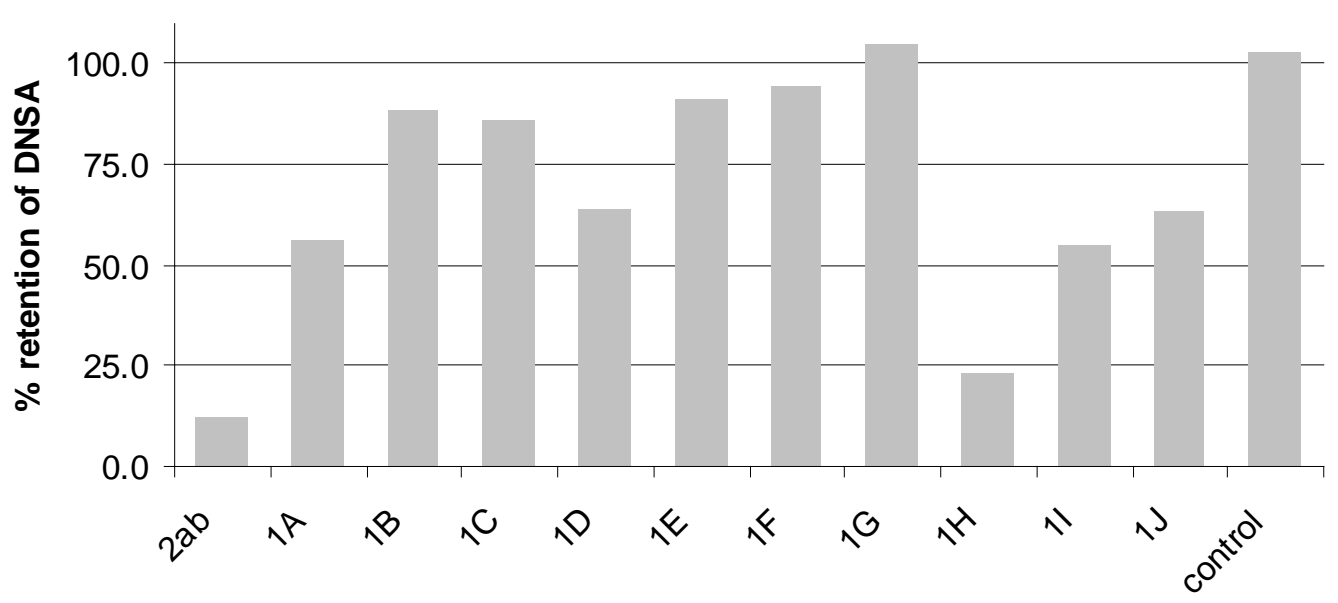

pDCL product, $10 \mu \mathrm{M}$

${ }^{a}$ Control experiment is assay result from immobilized metathesis catalyst only. 


\section{Figure Legends}

Figure 1. Aromatic sulfonamides used clinically for therapeutic intervention with carbonic anhydrases.

Figure 2. Alkene cross metathesis reaction.

Figure 3. A. Building block 1 with dual functionality: an aromatic sulfonamide moiety (bCA II recognition fragment) and a terminal alkene (for CM). B. Building blocks A-J, each contain a terminal alkene for CM. C. Possible self-CM products from building block $\mathbf{1}$ (2ab is prepared by CM, 2a and $\mathbf{2 b}$ prepared as trans- and cis- isomers by an alternative synthesis ${ }^{27}$ ).

Figure 4. A. ESI MS negative ion mass spectrum of the cross metathesis reaction of 2a and building block A. B. ESI MS negative ion mass spectrum following the addition of building block $\mathbf{C}$ to cross metathesis reaction shown in Figure 4A.

Figure 5. A. Self-CM products AA-JJ generated in pDCLs prepared from building blocks AJ. B. bCA II enzyme binding screen results at $1 \mu \mathrm{M}$ and $10 \mu \mathrm{M}$ for self-CM pDCLs.

Figure 6. A. Preparation of pDCLs from 1 and each of A-J. B. bCA II enzyme binding screen results at $1 \mu \mathrm{M}$ and $10 \mu \mathrm{M}$ for CM pDCLs. 